\title{
Differential Diagnosis of Children with Short Stature Not Associated with Metabolic, Chromosomal, or Gross Nervous System Defects
}

\author{
BARBARA E. CLAYTON, J. M. TANNER, G. H. NEWNS, \\ R. H. WHITEHOUSE, and A. G. L. RENWICK \\ From the Departments of Chemical Pathology and Growth and Development, Institute of Child Health, Guilford Street, \\ and The Hospital for Sick Children, Great Ormond Street, London W.C.1
}

Administration of human growth hormone (HGH) is an effective way of making some very short children grow. The supply of the hormone is inevitably restricted, however, so it is important to try to select correctly those children who will most benefit from the treatment.

The differential diagnosis of children with short stature presents considerable difficulty when stunted growth is not associated with a gross structural abnormality, such as a craniopharyngioma, in the hypothalamico-pituitary region. In the absence of such a lesion, it is hard to distinguish small normal children, or those simply with retarded growth, from those with hormonal inadequacy due to failure of hypothalamic releasing factors or failure in the anterior lobe of the pituitary gland. The situation is further complicated should the birthweight be low.

This paper describes an attempt to differentiate some types of patient who complain of failure to grow. The study extends back over a number of years, and so growth hormone levels are not available on these patients. Classification has been made on clinical and auxological grounds, and the results of laboratory investigations have then been related.

\section{Patients and Their Classification}

We have excluded from consideration here all children with known pituitary or brain lesions, or with metabolic or chromosomal disorders. The remainder total 55 . They have been divided into three categories entirely on clinical and auxological grounds, with particular reference where possible to the manner in which the child grew in the years following initial testing (summarized in Tables I-III

Received September 12, 1966. below). The biochemical findings have not been used to assist in classification.

The three categories are: (1) small normal children (21 children); (2) low birthweight dwarfs (9 children); (3) hyposomatotrophic dwarfs (25 children).

These categories are certainly not to be regarded as immutable divisions, at least at this stage of our knowledge. But they are a useful device for handling our data, and the classification of each individual patient represents a crucial problem. The patients are listed in Tables I, II, and III below.

Small normal. When a child was not very far below the 3rd centile for height and gradually and spontaneously caught up towards it as growth proceeded, we classified him as a small normal, particularly if one or both parents were very small. No. 1.17 (Table I), for instance, was 4.0 standard deviations less than average height at age $9 \cdot 7$ years, but her parents and grandparents were all remarkably small. Her predicted adult height was $150 \mathrm{~cm}$. (59 in.) which was at the same centile level as the average of her father and her two grandfathers, and only slightly below the centile level of her mother and her two grandmothers; hence we classified her as small normal. Two children with low birthweights, Nos. 1.9 and 1.15, who subsequently reached the 3rd centile, were included amongst the small normals.

Low birthweight dwarfs. In the low birthweight (LBW) dwarf category we placed children who were well below the 3rd centile for height and whose birthweight was below $2 \cdot 0 \mathrm{~kg}$. $\left(4 \frac{1}{2} \mathrm{lb}\right.$.) as suggested by Warkany, Monroe, and Sutherland (1961) and Black (1961). We have included 4 


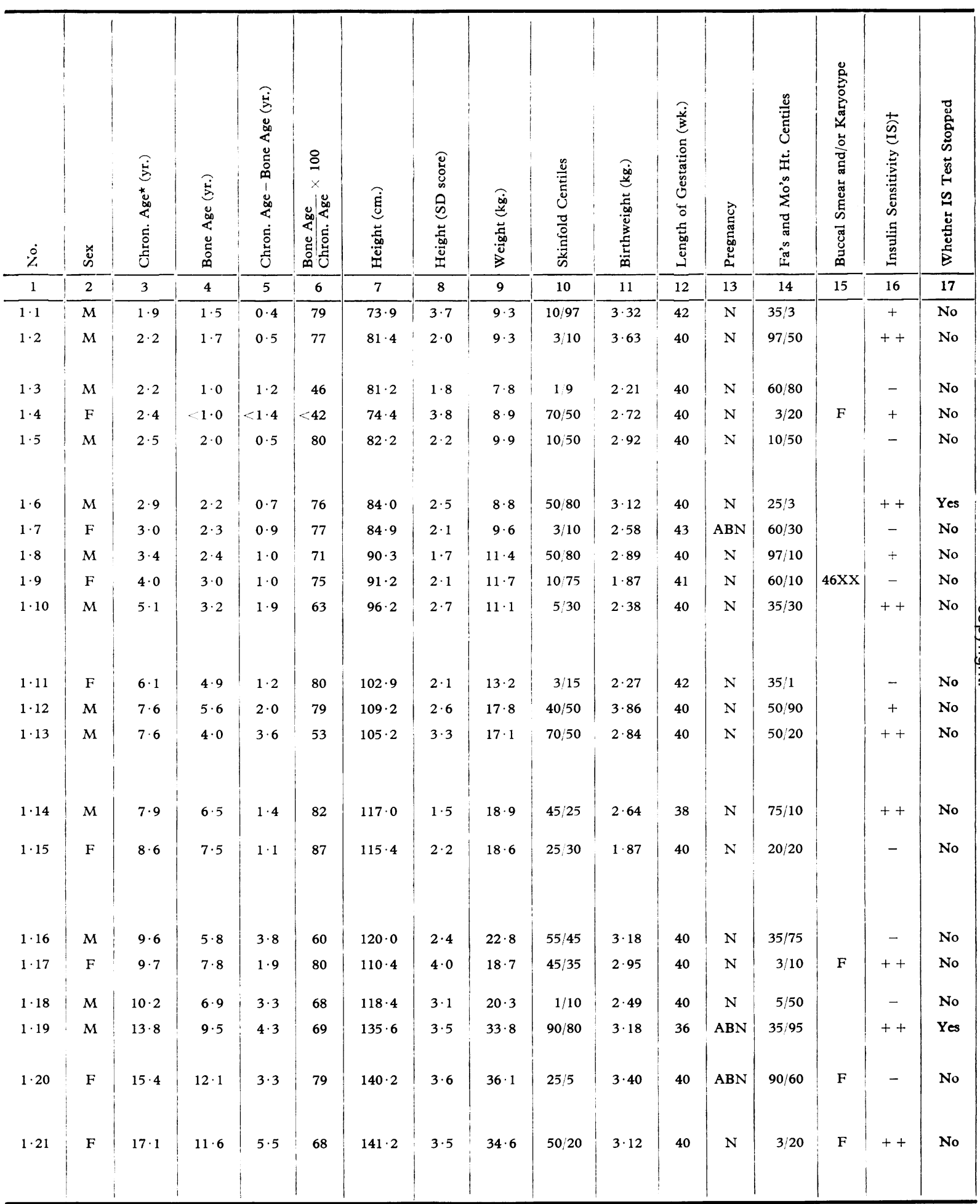

Age at investigation. $\ddagger++$ represents fall of $15 \%$ in blood sugar without sign

$\stackrel{F}{\mathrm{~S} S \mathrm{~F}}=$ secondary sexual characters. $\mathrm{PH}=$ pubic hair rating on scale 1 to 5 . $\mathbf{B}=$ breast rating on scale 1 to 5 . $\mathrm{G}=\mathrm{genitalia}$ rating in males 


\begin{tabular}{|c|c|c|c|c|c|c|c|c|}
\hline 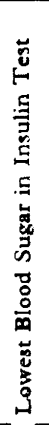 & 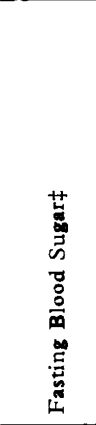 & 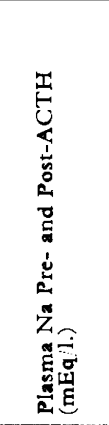 & 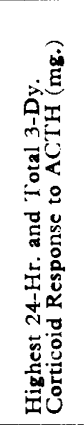 & 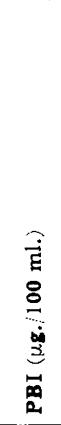 & 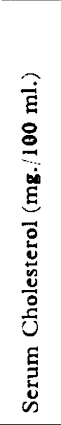 & 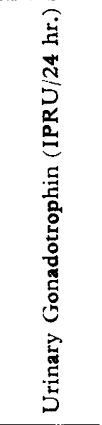 & & \\
\hline 18 & 19 & 20 & 21 & 22 & 23 & 24 & 25. Other Clinical Details & 26. Course \\
\hline 40 & $65(3)$ & $141 /-$ & $15-$ & $5 \cdot 6$ & 254 & 0.4 & & Age 3.4, bone age $2 \cdot 6, \mathrm{ht} .85 \cdot 0 \mathrm{~cm}$. \\
\hline 32 & $51(2)$ & $134-$ & 920 & $6 \cdot 7$ & 167 & - & & $\begin{array}{l}\text { Age } 3 \text {, bone age 20th centile, } \\
\text { ht, 10th centile; ACTH } 50 \\
\text { U/day } 2 \cdot 6 \text { to } 3 \cdot 6 \text {, little effect on }\end{array}$ \\
\hline 70 & $80(2)$ & 135:- & 1427 & - & 178 & $<0.6$ & & $\begin{array}{l}\text { Age } 5.9 \text {, bone age } 4.4 \text { (ratio } 74 \% \text { ) } \\
\text { ht. 3rd centile }\end{array}$ \\
\hline 55 & $79(2)$ & $136-$ & 13:- & $5 \cdot 4$ & - & $0 \cdot 2$ & Father often in prison; social conditions & Age 3.6, bone age 1.9 (ratio $53 \%$ ) \\
\hline 71 & $81(1)$ & 137138 & $15 / 39$ & $6 \cdot 5$ & 187 & $<1.5$ & $\begin{array}{l}\text { Much diarrhoea and vomiting during } \\
\text { infancy-no cause found; gluten- } \\
\text { free diet at } 14 \text { mth., but not } \\
\text { continued; probably chiefly food } \\
\text { refusal problem, brother sme }\end{array}$ & $\begin{array}{l}\text { Age } 6.5 \text {, bone age } 4.3 \text {, ht. } 1 \mathrm{st} \\
\text { centile }\end{array}$ \\
\hline 37 & $56(2)$ & -- & 17.21 & $5 \cdot 0$ & - & $0 \cdot 2$ & & Age $4 \cdot 7$, bone age $3 \cdot 5$, ht. $93 \cdot 8$ \\
\hline 84 & $88(4)$ & $139: 138$ & 1829 & $6 \cdot 7$ & 164 & $0 \cdot 22$ & $\begin{array}{l}\text { Hyperemesis in preg. 2nd born twin, } \\
\text { IO } 94\end{array}$ & $\begin{array}{l}\text { Age } 4 \cdot 7 \text {, bone age } 3 \cdot 7 \text {, ht. at } 3 \mathrm{rd} \\
\text { wt. at } 1 \text { st centile }\end{array}$ \\
\hline 35 & $77(4)$ & $136 / 142$ & $23 / 47$ & $4 \cdot 7$ & 212 & 0.42 & & Age 6.4, bone age $5 \cdot 2$, ht. at 5 th, \\
\hline 82 & $97(4)$ & 142143 & 26.57 & $5 \cdot 9$ & - & $\therefore 0.4$ & Child Guidance Clinic patient & $\begin{array}{l}\text { Age } 6 \cdot 0 \text {, bone age } 6 \cdot 0 \text {, ht. 3rd } \\
\text { centile }\end{array}$ \\
\hline 37 & $65(1)$ & $135 !-$ & 1632 & $2 \cdot 9$ & 231 & $<0.4$ & $1 ;: 2$ I uptake normal & 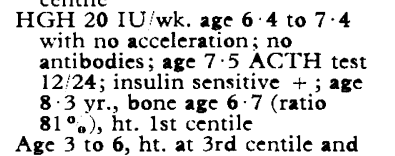 \\
\hline 62 & $78(3)$ & $143-$ & -- & $4 \cdot 2$ & 148 & $\begin{array}{r}0.4 \\
0.2\end{array}$ & IQ 110 & $\begin{array}{l}\text { bone age within normal limits } \\
\text { Age } 8 \cdot 2 \text {, bone age } 6 \cdot 2, \mathrm{ht} \text {. } 1 \mathrm{st} \\
\text { centile }\end{array}$ \\
\hline 56 & $92(1)$ & 138138 & $24: 46$ & $5 \cdot 4$ & - & 0.76 & $\begin{array}{l}\text { Father } 154 \cdot 9 \mathrm{~cm} \text {. at } 18 \mathrm{yr} .-175 \cdot 3 \mathrm{~cm} \text {. } \\
\text { at } 20 \mathrm{yr} \text {. did not shave till } 19 \mathrm{yy} \text {; } \\
\text { patient ESN? bird-like face (sister } \\
\text { same but size normal); hair on } \\
\text { extensor surfaces, arms, and back }\end{array}$ & $\begin{array}{l}\text { Age } 10 \cdot 4 \text {, bone age } 6.0 \text { (ratio } \\
58 \% \%) \text {, ht. } 116.0(\text { SD score } 3 \cdot 7) \text {; } \\
\text { at age } 8.8 \text { operated for Legg- } \\
\text { Perthes }\end{array}$ \\
\hline 63 & $118(1)$ & 135.139 & 25.49 & $4 \cdot 4$ & 220 & - & $\begin{array}{l}\text { Sister pyloric stenosis died } 4 \text { mth.; } \\
\text { brother died } 24 \mathrm{hr} \text {. Hypoplastic } \\
\text { lungs }\end{array}$ & $\begin{array}{l}\text { Age 6-10, bone age 10th centile, } \\
\text { ht. 1st centile }\end{array}$ \\
\hline 84 & $96(1)$ & 140137 & $33: 53$ & $5 \cdot 8$ & 167 & $\therefore 1 \cdot 5$ & & $\begin{array}{l}\text { Age } 12 \cdot 8 \text {, bone age } 13 \cdot 0 \text {, ht. 10th } \\
\text { centile, menarche } 12 \cdot 4 ; \text { had } \\
\text { ACTH } 5 \text { U/day from age } 9.8 \\
\text { till } 11 \cdot 2 \text { without apparent effect } \\
\text { on ht. or bone age increment or } \\
\text { skinfolds; adol. spurt normal } \\
\text { shape } \\
\text { Age } 13 \text {, bone age } 9 \cdot 8 \text { (ratio } 75^{\circ} \text { ), }\end{array}$ \\
\hline 71 & $110(2)$ & 136- & 3685 & $5 \cdot 4$ & - & $\therefore 0 \cdot 2$ & $\begin{array}{l}\text { Mat. g. mother } 154.9 \mathrm{~cm} . ; \mathrm{g} \text {. father } \\
154.9 \mathrm{~cm} . ; \text { pat. g. mother } 154.9 \\
\mathrm{~cm} . ; \mathrm{g} \text {. tather } 162.6 \mathrm{~cm} \text {. }\end{array}$ & $\begin{array}{l}\text { Age } 11 \cdot 8 \text {, bone age } 10 \cdot 2 \text {, ht. } 121 \cdot 1 \\
\text { cm. (SDD score } 4.5) \text {, predicted } \\
\text { adult ht. } 149 \cdot 9 \mathrm{~cm} \text {. }\end{array}$ \\
\hline 72 & $127(5)$ & 136141 & $38: 86$ & $6 \cdot 0$ & - & $<0.3$ & IQ 94; father Cypr. 6 sibs & $\begin{array}{l}\text { At } 11 \cdot 0 \text {, bone age } 8 \cdot 1 \text {, ht. } 122 \cdot 6 \\
\mathrm{~cm} \text {. (SD score } 3 \cdot 1 \text { ) }\end{array}$ \\
\hline 28 & $70(2)$ & $138: 135$ & $14: 36$ & $7 \cdot 4$ & 200 & $<0.4$ & $\begin{array}{l}\text { Breech delivery; incubator } 24 \mathrm{hr} \text {; } \\
\text { IQ } 114\end{array}$ & $\begin{array}{l}\text { Age 15.9, bone age 13.0, ht. } 145.0 \\
\text { cm. (3rd centile). Age 17.7, ht. } \\
165.1 \mathrm{~cm} \text {. (8th centile) }\end{array}$ \\
\hline- & $11(4)$ & 134 & -- & - & - & $\begin{array}{l}\mathbf{0} \cdot 5 \\
\mathbf{0} \cdot 57\end{array}$ & 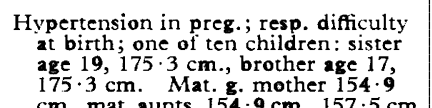 & $\begin{array}{l}\text { Menarche at 16.2, age } 16 \cdot 4 \text {, bone } \\
\text { age } 14 \cdot 3, \text { ht. } 143 \cdot 0 \mathrm{~cm} \text {. (SD } \\
\text { score } 3 \cdot 2 \text { ), SSC ratings Br } 5 \text {, } \\
\text { PH 4 }\end{array}$ \\
\hline 52 & $71(2)$ & 136- & 4692 & $7 \cdot 0$ & - & 0.5 & $\mathrm{IQ}_{93}^{\mathrm{cm}, 3^{\prime}}$ & $\begin{array}{l}\text { Menarche at } 19 \cdot 2 \text {, age } 19 \cdot 4 \text {, bone } \\
\text { age } 15 \cdot 0 \text {, ht. } 149.9 \mathrm{~cm} . \text { (SD score } \\
2 \cdot 0) \text { SSC ratings Br } 5, \mathrm{PH} 5 . \\
\text { Predicted adult height } 150 \cdot 4 \mathrm{~cm} \text {. }\end{array}$ \\
\hline
\end{tabular}




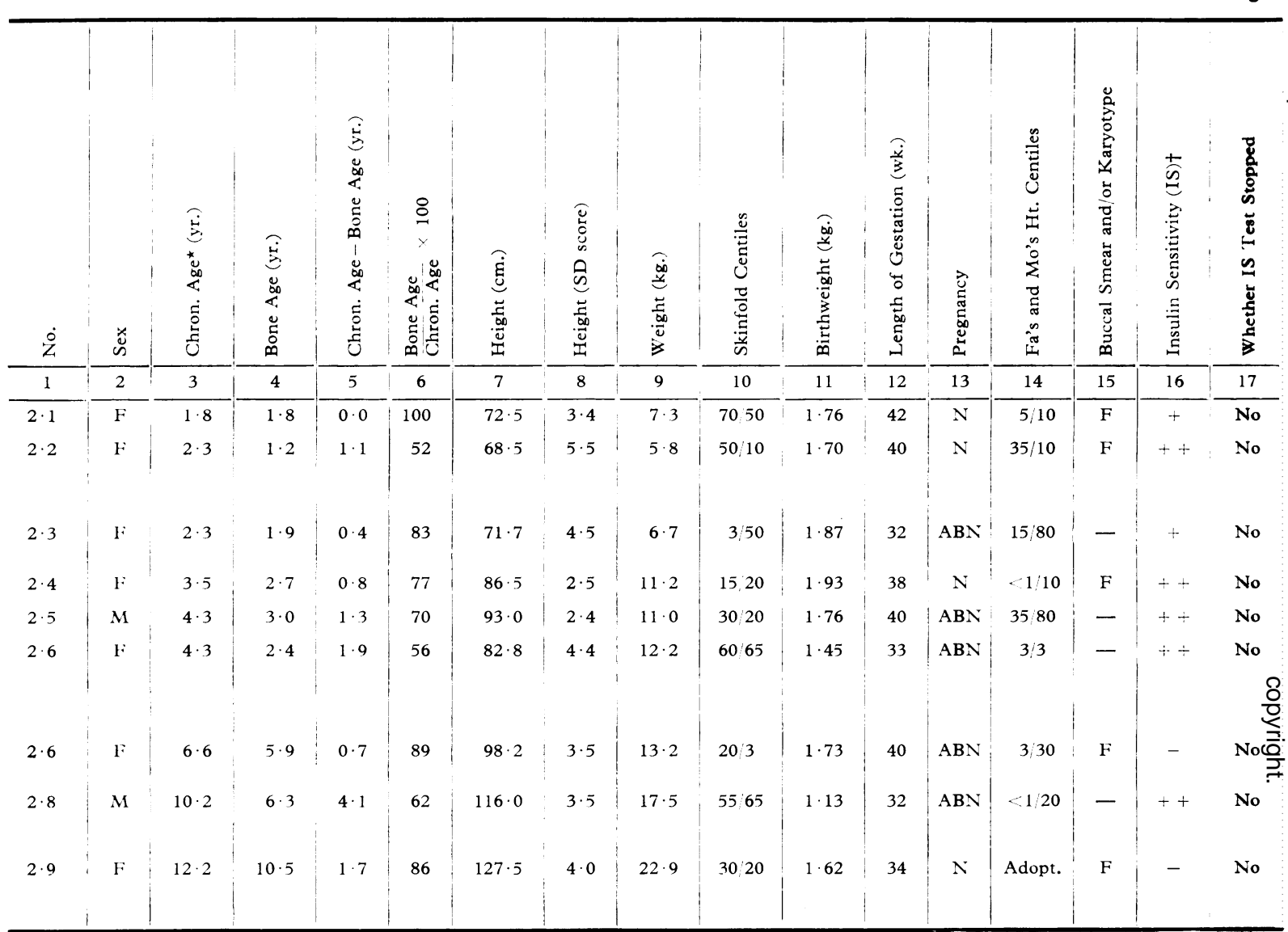

For footnotes see Table I.

children who were born prematurely; of these 2 were clearly small for dates, but 2 were only borderline. Some of these children may really be small normals (No. 2.5 for instance, who is at the 1st centile for height at age $6 \cdot 1$ years) or have reasons other than intrauterine pathology for being dwarfed. No. 2.9, for example, born at 34 weeks' gestation, weighing $1.62 \mathrm{~kg}$. was an adopted child. When adult she will be about $3 \cdot 0$ standard deviations below the mean for height, but this may perhaps be due to the persistent effects of early neglect, the history of which is not clear.

Hyposomatotrophic dwarfs. It is children in the third category, whom we call hyposomatotrophic dwarfs (see Mason and Tanner, 1967), that we think suffer from a specific lack of secretion or lack of action of growth hormone. The chief factors which influenced us in placing a child in this category were threefold: (1) very small for his age and showing no tendency to catch up as growth progressed, (2) a severely retarded bone-age (with normal PBI), and (3) a good growth response to HGH. If growth hormone was given and a good response obtained, we invariably placed the child in this category. A poor response did not necessarily exclude a child from the category, since this might be due to a variety of causes. Only one child (No. 1.10) actually treated with $\mathrm{HGH}$ was finally classified amongst the small normals. Later work has led us to think that high skinfolds, indicating much subcutaneous fat, and a relatively short trunk compared with length of legs are also indications that a short child should be placed in this category (Tanner and Whitehouse, 1967). At the limit the differentiation between this category and that of 
II

Dwarfs

\begin{tabular}{|c|c|c|c|c|c|c|c|c|}
\hline 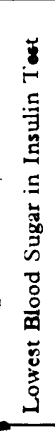 & 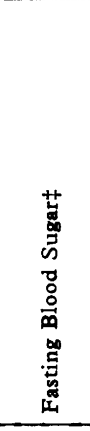 & 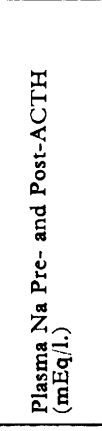 & 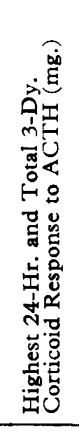 & 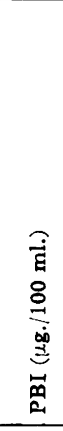 & 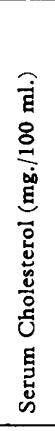 & 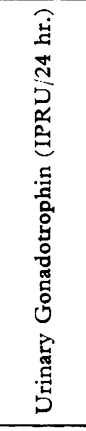 & & \\
\hline 18 & 19 & 20 & 21 & 22 & 23 & 24 & 25. Other Clinical Details & 26. Course \\
\hline 50 & $67(4)$ & $142 / 134$ & $26 / 56$ & $5 \cdot 0$ & 161 & $<0.4$ & Eczema, asthma, hayfever syndrome & Age $4 \cdot 9$, bone age $3 \cdot 7$, ht. $89 \cdot 6$ \\
\hline 52 & $55(2)$ & $134 / 135$ & 914 & $5 \cdot 1$ & - & - & $\begin{array}{l}\text { Alleged hydrocephalus and air studies } \\
\text { done age } 5 \text { mth.; suspected slight } \\
\text { atrophy cortex, but now has no } \\
\text { neurolog. symptoms; IQ } 123 \\
\text { age } 3 \cdot 2\end{array}$ & $\begin{array}{l}\text { Age } 3 \cdot 2 \text {, bone age } 1 \cdot 7, \text { ht. } 74 \cdot 7 \\
\mathrm{~cm} .(\mathrm{SD} \text { score } 5 \cdot 0)\end{array}$ \\
\hline 30 & $\begin{array}{l}55(2) \\
87(2)\end{array}$ & $136 / 138$ & $\begin{array}{r}7,11 \\
23,53\end{array}$ & $\begin{array}{l}4 \cdot 0 \\
6 \cdot 6\end{array}$ & - & - & $\begin{array}{l}\text { Breech delivery; premature, but not } \\
\text { small for dates }\end{array}$ & $\begin{array}{c}\text { ACTH } 5 \text { U daily from age } 2 \cdot 3 \text { to } \\
3 \cdot 1 \text { yr.; age } 4 \cdot 3 \text {, bone age } 3 \cdot 2 \text {, } \\
\text { ht. } 86 \cdot 6 \mathrm{~cm} \text {. (SD score } 3 \cdot 6 \text { ) } \\
\text { Age } 4 \cdot 4 \text {, bone age } 3 \cdot 2 \text {, ht. } 91 \cdot 7 \\
\text { cm. (SD score } 2 \cdot 5 \text { ) }\end{array}$ \\
\hline 52 & $65(5)$ & $143 / 144$ & $29 / 59$ & $3 \cdot 5$ & 146 & $<0 \cdot 2$ & $\begin{array}{l}\text { Haemorrhages during pregnancy, at } \\
6 \text { and } 12 \mathrm{wk} \text {. }\end{array}$ & $\begin{array}{l}\text { Age } 6 \cdot 1 \text {, bone age } 4 \cdot 9 \text {, ht. } 103 \cdot 8 \\
\mathrm{~cm} \text {. (SD score } 2 \cdot 2 \text { ) }\end{array}$ \\
\hline 48 & $70(2)$ & $138 / 135$ & $14 / 36$ & $7 \cdot 4$ & 200 & $<0.4$ & $\begin{array}{l}\text { Loose fatty stools; Giardia lamblia } \\
\text { found and treated; palpable liver; } \\
\text { fat balance, } \mathrm{B} 12 \text {, folic acid, } x \text {-ray films } \\
\text { normal; twin (other died } \\
\text { neonatally); iron deficiency at } \\
11 \text { mth. }\end{array}$ & $\begin{array}{l}\text { Age } 5 \cdot 3 \text {, bone age } 3 \cdot 4 \text {, ht. } 89 \cdot 2 \\
\text { cm. (SD score } 4 \cdot 1 \text { ), family } \\
\text { psychol. circums. bad; in child } \\
\text { guidance clinic }\end{array}$ \\
\hline 56 & $20(3)$ & $138:-$ & $6 / 16$ & $7 \cdot 6$ & - & $<0 \cdot 2$ & $\begin{array}{l}\text { Toxaemia of pregnancy, thrombosis, } \\
\text { dindevan, placental infarct; at } \\
\text { child guidance clinic, IQ } 130\end{array}$ & $\begin{array}{l}\text { Age } 7 \cdot 1 \text {, bone age } 6 \cdot 3 \text {, ht. } 100 \cdot 4 \\
\text { cm. (SD score } 3 \cdot 8 \text { ) }\end{array}$ \\
\hline 69 & $100(1)$ & $135 / 135$ & $15 \%$ & $6 \cdot 3$ & - & $<0.4$ & $\begin{array}{l}\text { One of triplets; two others died at } \\
\text { birth; mother } 40 \text { at pregnancy; } \\
\text { ESN school }\end{array}$ & $\begin{array}{l}\text { Age } 14 \cdot 5 \text {, bone age } 10 \cdot 3 \text {, ht. } 135 \cdot 4 \\
\text { cm. (SD score } 4 \cdot 5 \text { ); SSC ratings } \\
\text { G } 1 \text {, PH } 2 \text {; prediction gives } \\
\text { above either parent's height }\end{array}$ \\
\hline 80 & $94(2)$ & $139 / 143$ & $29 / 73$ & $5 \cdot 8$ & 200 & $1 \cdot 3$ & $\begin{array}{l}\text { Premature; not very small for dates: } \\
\text { may be really hyposomatotrophic } \\
\text { dwarf }\end{array}$ & $\begin{array}{l}\text { Menarche } 13 \cdot 4 \text { yr., age } 16 \cdot 5 \text {, bone } \\
\text { age } 16 \cdot 0, \text { ht. } 143 \cdot 1 \mathrm{~cm} \text {. (SD } \\
\text { score } 3 \cdot 2 \text { ), Br } 5, \mathrm{PH} 5\end{array}$ \\
\hline
\end{tabular}

small normal may be meaningless; small normals may have a lower-than-average secretion of growth hormone, and this may shade imperceptibly into the clearly pathological case where the secretion is lower still.

A number of dubiously classified children inevitably remain; amongst the hyposomatotrophic dwarfs, No. 3.15 might really be a small normal. Though her parents are not very small, three of her grandparents are.

Particular difficulty arises over children who are simply very retarded in growth. There are some who enter adolescence 6 or even 8 years late, and eventually reach a perfectly normal height. Around the age of 4 to 10 these cannot always be differentiated from hyposomatotrophic dwarfs by their size or bone-age, or even at present on biochemical grounds. No. 1.13 (Table I) amongst the small normals is probably one of these, as was his father. No. 1.21 is another, who had her menarche at $19 \cdot 2$ and will eventually reach the third centile. No. 1.19 is a third: he was 3.5 standard deviations below the mean height at age 13.8 when he was first seen, and his bone age was $4 \cdot 3$ years retarded; but without treatment he reached the 3 rd centile at 15.9 and the 8 th centile at $17 \cdot 7$ years.

Another difficulty is provided by children with gonadal dysgenesis associated with a chromosome mosaic. These may have a normal buccal smear; we eliminated two such patients only in the last draft of this paper. The first was seen at age 16.6, had a bone age of 11.0 (unusually retarded for gonadal dysgenesis), was insulin one-plus sensitive, and had an ACTH response below normal. At age 20.9 she had no secondary sex development or menarche. Her karyotype was $\mathrm{XO} / \mathrm{XX}$. The 


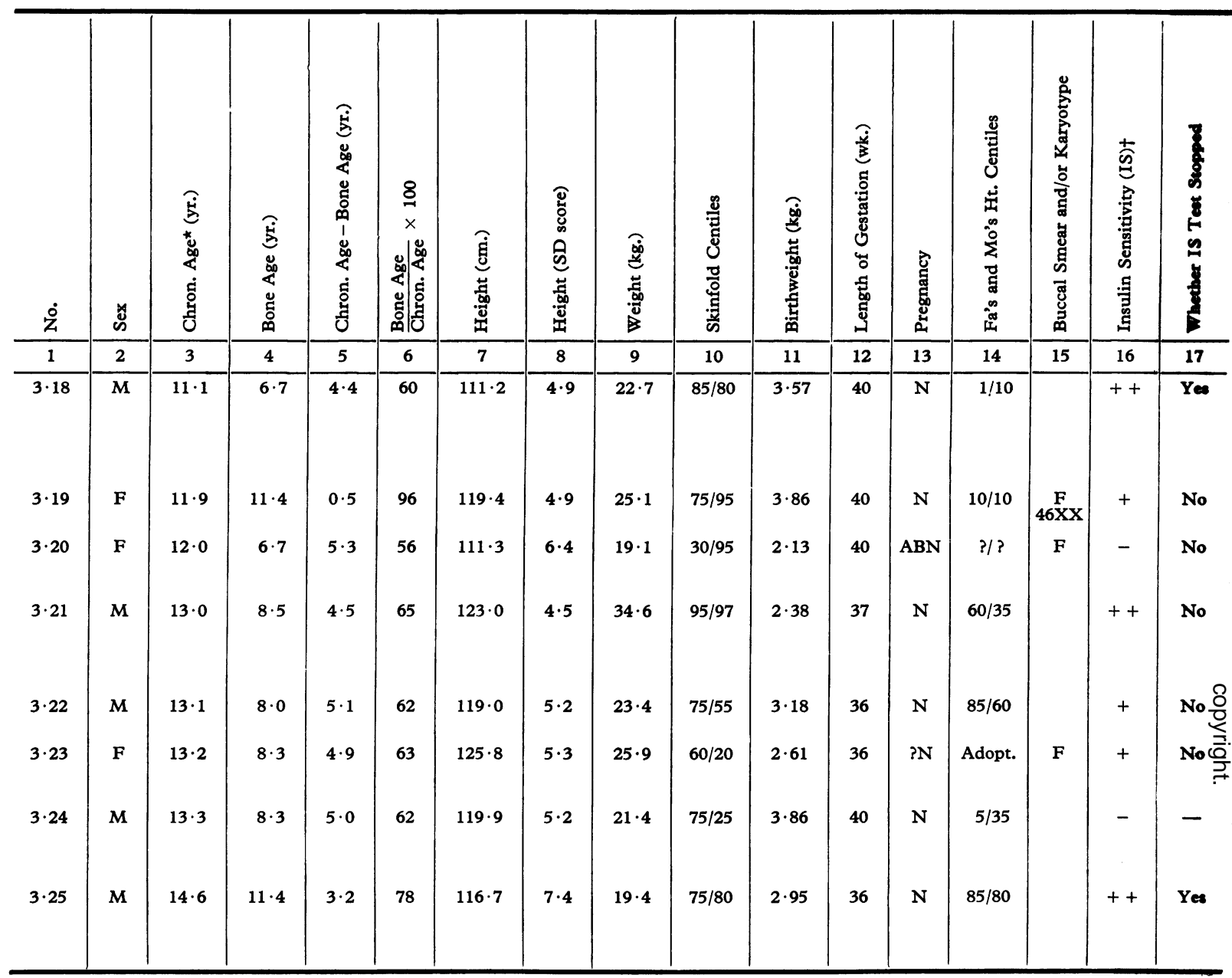

For footnotes see Table I.

second was first seen at age 10:1. Her bone age was $8 \cdot 2(81 \%$ of chronological age and so within normal limits). She was insulin two-plus sensitive and her ACTH response was below normal. She was treated for a year with human growth hormone but only grew $4 \cdot 4 \mathrm{~cm}$. Her karyotype was $\mathrm{XO} / \mathrm{XXi}$. Evidently all short girls should have their karyotype examined, even if the buccal smear is normal.

A third difficulty is provided by children with tumours of the nervous system not associated with calcium deposition and not sufficiently large to cause any symptoms except, apparently, shortness. One such was also eliminated from the hyposomatotrophic dwarfs in the last draft. She was first seen at age $13 \cdot 1$, with bone age $10 \cdot 4$, height SD score
3.3, insulin two-plus sensitive, ACTH response below normal, PBI $4.3 \mu \mathrm{g} . / 100 \mathrm{ml}$. Her skull $x$-ray film was reported as normal. She grew little in response to $\mathrm{HGH}$, but ceased to grow at all when HGH was stopped. After 2 years she developed optic neuritis and an air encephalogram showed a tumour which on operation was found to be a pinealoma. Comparison of skull $x$-ray films two years apart showed a distinct change, even though each would have passed for normal in the absence of the other. Probably small children should have lateral skull $x$-ray examination every year.

\section{Methods}

(a) Auxological. Skeletal maturity of the left hand 


\begin{tabular}{|c|c|c|c|c|c|c|c|c|}
\hline 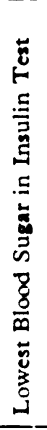 & 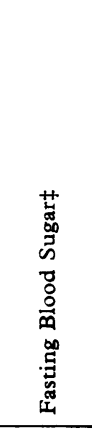 & 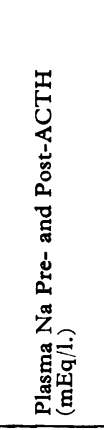 & 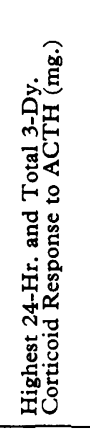 & 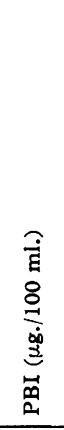 & 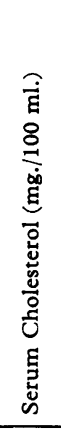 & 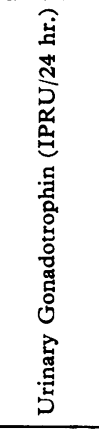 & & \\
\hline 18 & 19 & 20 & 21 & 22 & 23 & 24 & 25. Other Clinical Details & 26. Course \\
\hline 26 & $108(1)$ & $141 /-$ & $26 / 54$ & $4 \cdot 5$ & $\begin{array}{l}220 \\
275\end{array}$ & $\begin{array}{l}0.42 \\
0.25\end{array}$ & & $\begin{array}{l}\text { HGH } 10 \mathrm{IU} / \mathrm{wk} . \text {, age } 11 \cdot 4 \text {; in } 1 \mathrm{st} \\
\text { yr. grew } 5 \cdot 5 \mathrm{~cm} ., 2 \text { nd yr. ( } 30 \\
\text { IU/wk.) grew } 6 \cdot 0 \mathrm{~cm} \text {., 3rd yr. } \\
\text { (15 IU, IUk.) grew } 6 \cdot 8 \mathrm{~cm} \text {; at age } \\
15 \cdot 7 \text {, bone age } 12 \cdot 5, \mathrm{SSC} \\
\text { ratings G } 3 \text {, PH } 1 ; \text { ht. } 131 \cdot 8 \mathrm{~cm} \text {. } \\
\text { (SD score } 6 \cdot 0 \text { ) } \\
\text { Age } 13 \cdot 9 \text {, bone age } 12 \cdot 0 \text {, ht. } 125 \cdot 3 \\
\text { cm. (SD score } 5 \cdot 9 \text { ); SSC ratings } \\
\text { Br } 3 \text { PH }\end{array}$ \\
\hline 75 & $97(2)$ & $139 / 138$ & $29 / 82$ & $5 \cdot 7$ & 138 & $<0.5$ & Twin, other stillborn; IQ 59 & $\begin{array}{l}\text { Menarche 14.8; age } 15 \cdot 5 \text {, bone age } \\
13 \cdot 5 \text {, ht. } 132 \cdot 1 \mathrm{~cm} \text {. (SD score } \\
5 \cdot 0) \text { SSC ratings } \mathrm{Br} 4 \text {, PH } 4 \text {, } \\
\text { predicted adult ht. } 137.5 \mathrm{~cm}\end{array}$ \\
\hline 50 & $75(2)$ & $138 /-$ & $54 / 120$ & - & - & $<0.6$ & Hypoplastic genitalia & $\begin{array}{l}1 \text { yr. on } \mathrm{HGH} 18 \mathrm{IU} / \mathrm{wk} \text {., starting } \\
\text { age } 14 \cdot 4 ; \text { in } 1 \mathrm{st} 6 \mathrm{mth} \text {. grew at } \\
\text { rate of } 8 \cdot 9 \mathrm{~cm} \text {. } / \mathrm{rr} \text {., then } \\
\text { developed } \mathrm{HGH} \text { antibodies in } \\
\text { low titre and for } 2 \text { nd } 6 \mathrm{mth} \text {. grew } \\
\text { at } 2.4 \mathrm{~cm} \text {. } / \mathrm{yr} \text {. }\end{array}$ \\
\hline 66 & $104(2)$ & $137 /-$ & $26 / 45$ & $3 \cdot 6$ & 282 & $<1.5$ & $\begin{array}{l}\text { Thyroxine age } 14 \cdot 1 \text { onwards, } 0.2 \mathrm{mg} . \\
\text { daily }(\mathrm{PBI} 3 \cdot 6)\end{array}$ & $\begin{array}{l}\text { Testosterone } 17 \cdot 1 \text { yr. onwards; at } \\
19 \cdot 0 \text {, bone age } 14 \cdot 3 \text {, ht. } 150 \cdot 8 \\
\mathrm{~cm} \text {. (SD score } 3 \cdot 6 \text { ) }\end{array}$ \\
\hline 65 & $91(2)$ & $135 / 138$ & $38 / 75$ & $4 \cdot 1$ & 288 & $1 \cdot 2$ & IQ 114 & $\begin{array}{l}\text { Age } 16 \cdot 4, \text { bone age } 10 \cdot 5, \mathrm{SSC} \\
\text { ratings } \mathrm{Br} 2 \text {, PH } 1 ; \text { age } 18 \cdot 0, \\
\text { ht. } 140 \cdot 0 \mathrm{~cm} \text {. (SD score } 3 \cdot 8) \text {; } \\
\text { no menarche yet }\end{array}$ \\
\hline - & $89(5)$ & $131 / 143$ & $11 / 26$ & $4 \cdot 7$ & - & $\begin{array}{l}<0 \cdot 2 \\
<0 \cdot 2\end{array}$ & $\begin{array}{l}\text { On cortisone } 2.5 \mathrm{mg} \text {. daily since age } \\
13.6\end{array}$ & $\begin{array}{l}\text { HGH } 12 \mathrm{IU} / \text { wk., age } 13 \cdot 9 \text {; in } 1 \mathrm{st} \\
\text { yr. grew } 8 \cdot 6 \mathrm{~cm} \text {; at age } 15 \cdot 0 \text {, } \\
\text { bone age } 9 \cdot 9, \mathrm{SSC} \text { ratings } \mathrm{G} 1 \text {, } \\
\text { PH } 1 \text {, ht. } 128 \cdot 8 \mathrm{~cm} \text {. (SD score } \\
6.0 \text { ) }\end{array}$ \\
\hline 36 & $87(3)$ & $136 / 134$ & $48 / 92$ & $4 \cdot 9$ & 248 & $<0.4$ & & $\begin{array}{l}\text { HGH } 24 \mathrm{IU} / \mathrm{wk} ., \text { age } 15 \cdot 1 \text {; gained } \\
\text { at } 4 \cdot 8 \mathrm{~cm} \text {. } / \mathrm{yr} ., 2 \cdot 8 \mathrm{~cm} . / \mathrm{yr} ., 1 \cdot 6 \\
\text { cm./yr. in first } 3 \text { quarters; } \\
\text { antibodies demonstrated }\end{array}$ \\
\hline
\end{tabular}

and wrist was determined according to the method and standards of Tanner, Whitehouse, and Healy (1962) for British children, and is reported here as bone age. All ratings were done by one observer (R.H.W.).

Height. All measurements were done by one of us (R.H.W.) according to the method detailed by Tanner (1958), with the child stretched to the maximum height by gentle traction under the mastoid processes. Conventionally, small children are identified by reference to their centile position on the normal standards, those below the 3rd centile being regarded as small. But a different system has to be used for showing how far below the 3 rd centile very small children are, since the location of the 1st and lower centiles is not accurately known. Hence we have calculated a 'height SD score' for each child: this simply represents the number of standard deviations the child is below the mean height for children of his age. This is a convenient but arbitrary measure.
A statistical interpretation cannot be put on the score; for example, a score of 4.0 does not mean that $0.0032 \%$ of healthy children are smaller than this. The distribution of height at each year of age is not sufficiently perfect in its normality for this to be true, nor is the estimate of the standard deviation at each age sufficiently precise. The SD scores corresponding to the 1st, 3rd, and 10th centiles are approximately $2 \cdot 3,1 \cdot 9$, and $1 \cdot 3$. The standards used for the means and SDs were those of Tanner, Whitehouse, and Takaishi (1966).

Weight was taken in the nude.

Skinfolds over triceps and under scapula were measured by one of us (R.H.W.) using the Harpenden skinfold calipers. Centile positions were read by reference to standards for London children (Tanner and Whitehouse, 1962).

(b) Biochemical. Plasma electrolytes, blood urea, 
blood sugar, and serum cholesterol on heel or fingerprick blood were determined by standard microprocedures (Wilkinson, 1960). Plasma calcium was determined with an Eppendorf flame photometer.

Anterior pituitary function was assessed by the following tests. (1) Insulin sensitivity by the method of Daniel (1941), using half the standard dose, i.e. 0-125 units soluble insulin $/ \mathrm{kg}$. body weight. The blood sugar was estimated at $20,40,60$, and 120 minutes after the subcutaneous injection of the insulin. If the blood sugar dropped by more than $15 \%$ from the pre-insulin level and the drop was sustained throughout the 2 hours, or if hypoglycaemic symptoms developed so that the test had to be terminated, this has been recorded as ++ in Table I. If, after initially dropping $15 \%$, the blood sugar rose again by $5 \mathrm{mg}$. at 2 hours or before, compared with its lowest value, the response has been recorded as + in Table $\mathbf{I}$.

(2) Serum protein-bound iodine (PBI) on venous blood, was determined by the method of Grossmann and Grossman (1955). (Normal range $3 \cdot 3$ to $7 \cdot 5 \mu \mathrm{g} . / 100$ $\mathrm{ml}$. in our age range.)

(3) If the PBI was low, the thyroid uptake of ${ }^{132} I$ was measured at varying intervals after $5 \mathrm{mc}^{132} \mathrm{I}$ given orally. If the uptake was low it was repeated after three days' stimulation with thyrotrophic hormone (5 units daily intramuscularly, Armour Laboratories Ltd.).

(4) The adrenocorticotrophic hormone (ACTH) stimulation test was performed by the method of Clayton, Edwards, and Renwick (1963). On the day of peak excretion (2nd or 3rd day on ACTH) normal children excrete an average of $32 \mathrm{mg}$. total 17-hydroxycorticoids, with a lower limit of $20 \mathrm{mg}$. $/ 24 \mathrm{hr}$. The total output during three days' stimulation with ACTH averages $71 \mathrm{mg}$. with a lower limit of $37 \mathrm{mg}$.

\section{Results}

In Tables I, II, and III are recorded a number of auxological and biochemical measurements, some further clinical details, and the course of the child's growth from the time of the first examination up to the present or to the last time seen. In each of the three diagnostic groups the children are arranged in ascending order of chronological age, given in column 3. Sex is given in column 2; chronological age at the time of investigation in column 3; and bone age at this time in column 4 .

The retardation of bone age is shown in column 5 by chronological age less bone age, and in column 6 by the ratio bone age/chronological age. These two columns give essentially the same information but the ratio is probably better for comparing the degree of retardation of older and younger children.

Height and height SD score are given in columns 7 and 8; weight in column 9. Skinfold centiles are in column 10; the first figure here represents the skinfold measured over the triceps and the second that measured below the angle of the scapula.
Column 11 gives the birthweight in kg.; column 12 the length of gestation in weeks as recorded in the medical history or obtained by questioning the mother. Column 13 designates pregnancy as normal $(\mathrm{N})$ or abnormal ( $\mathrm{ABN}$ ); in the latter case details are given in the penultimate column.

Column 14 gives the fathers' and mothers' heights in terms of centiles (taken from the 1965 British standards as figures for 19-year-olds). The father's is the first figure, the mother's the second. Most were only obtained by asking the mother, though some of the mothers were measured by us.

In column 15 the result of a buccal smear or karyotype is given where available.

For the insulin sensitivity test, column 16 records the response as + or ++ , as described under methods, column 17 states whether the test was terminated or not, and column 18 records the lowest blood sugar reached during the test. Column 19 records the average of a number of determinations of overnight fasting blood sugar. Column 20 gives plasma sodium before and after ACTH, and column 21 the response to ACTH in terms of the highest 24-hour total of 17-hydroxycorticoids and their total 3-day excretion. Column 22 gives the PBI, column 23 the cholesterol, and column 24 the gonadotrophin excretion.

Comparison of three groups. The proportions of boys to girls are $13: 8$ for small normals, $2: 7$ for low birthweight dwarfs, and $15: 10$ for hyposomatotrophic dwarfs. Possibly the excess of girls amongst the LBW dwarfs is indicative of something of aetiological interest, but it may be due simply to sampling error.

The major results of comparing the 3 groups are given in Table IV where the means and ranges of a number of variables are shown.

Bone age. Bone age was on average more retarded in the hyposomatotrophic dwarfs than in the normals or the LBWs, as can be seen from the second and third rows. The average retardation in the hyposomatotrophic dwarfs was $2 \cdot 7$ years, in the small normals 1.9 years, and in the LBWs 1.3 years. The average ratios were $57 \%$ chronological age, $71 \%$, and $75 \%$. The ranges show an almost complete overlap between the groups, but are a little deceptive. It turns out that a ratio of $65 \%$ divides fairly well the dwarfs from the small normals. Only 3 of the 25 dwarfs had a bone age less retarded than this, and only 5 of the 21 normals had a bone age more retarded. The 3 exceptional dwarfs may constitute a special group. Two of them (3.17 and 3.25) have been treated with $\mathrm{HGH}$ and both had a 
TABLE IV

Comparison of Means and Ranges of a Number of Variables in Small Normals, Low Birthweight Dwarfs and Hyposomatotrophic Dwarfs

\begin{tabular}{|c|c|c|c|c|c|c|c|c|c|c|c|}
\hline \multirow{2}{*}{\multicolumn{3}{|c|}{ Variable }} & \multicolumn{3}{|c|}{ Numbers } & \multicolumn{3}{|c|}{ Means } & \multicolumn{3}{|c|}{ Range } \\
\hline & & & Small & LBW & Hypos. & Small & LBW & Hypos. & Small & LBW & Hypos. \\
\hline \multirow{2}{*}{\multicolumn{3}{|c|}{$\begin{array}{l}\text { (3) Age at exam. (yr.) . } \\
\text { (5) Chron. age minus bone age (yr.) } \\
\text { (6) Bone age }\end{array}$}} & $\begin{array}{l}21 \\
21\end{array}$ & $\begin{array}{l}9 \\
9\end{array}$ & $\begin{array}{l}25 \\
25\end{array}$ & $\begin{array}{l}6 \cdot 8 \\
1 \cdot 9\end{array}$ & $\begin{array}{l}5 \cdot 3 \\
1 \cdot 3\end{array}$ & $\begin{array}{l}7 \cdot 2 \\
2 \cdot 7\end{array}$ & $\begin{array}{c}1 \cdot 9-17 \cdot 1 \\
0 \cdot 4-5 \cdot 5\end{array}$ & $\begin{array}{c}1 \cdot 8-12 \cdot 2 \\
0 \cdot 0-4 \cdot 1\end{array}$ & $\begin{array}{c}1 \cdot 6-14 \cdot 6 \\
0 \cdot 5-5 \cdot 3\end{array}$ \\
\hline & .. & .. & 21 & 9 & 25 & 71 & 75 & 57 & $42-87$ & $52-100$ & $38-96$ \\
\hline $\begin{array}{l}\text { (8) Height SD score } \\
\text { (10) Skinfolds (centiles) } \\
\text { (11) Birthweight (kg.) } \\
\text { (14) Parents' height centil }\end{array}$ & $\begin{array}{l}\cdots \\
\ddot{\operatorname{les}}(F / 1\end{array}$ & & $\begin{array}{l}21 \\
21 \\
21 \\
21\end{array}$ & $\begin{array}{l}9 \\
9 \\
9 \\
8\end{array}$ & $\begin{array}{l}25 \\
25 \\
25 \\
18\end{array}$ & $\begin{array}{l}2 \cdot 7 \\
31 / 41 \\
2 \cdot 84 \\
42 / 35\end{array}$ & $\begin{array}{l}3 \cdot 7 \\
37 / 34 \\
1 \cdot 65 \\
12 / 30\end{array}$ & $\begin{array}{c}5 \cdot 2 \\
56 / 68 \\
2 \cdot 97 \\
45 / 36\end{array}$ & $\begin{array}{l}1 \cdot 5-4 \cdot 0 \\
1-90 / 5-97 \\
1 \cdot 87-3 \cdot 86 \\
3-97 / 3-95\end{array}$ & $\begin{array}{l}2 \cdot 4-4 \cdot 5 \\
3-70 / 3-65 \\
1 \cdot 13-1 \cdot 93 \\
1-35 / 3-80\end{array}$ & $\begin{array}{c}3 \cdot 0-7 \cdot 4 \\
3-97 / 10-97 \\
2 \cdot 04-4 \cdot 11 \\
1-95 / 3-97\end{array}$ \\
\hline $\begin{array}{l}\text { (mg./100 ml.) } \\
\text { (19) Average fasting } \mathrm{s}\end{array}$ & sugar & & 20 & 9 & 24 & 59 & 54 & 44 & 28-84 & $30-80$ & $16-75$ \\
\hline $\begin{array}{l}\text { (mg./100 ml.) } \\
\text { (20) } \mathrm{Na}(\mathrm{mEq} / \mathrm{l} .) \quad \ldots\end{array}$ & $\cdots$ & $\cdots$ & $\begin{array}{l}21 \\
20 / 11\end{array}$ & $\begin{array}{c}9 \\
9 / 7\end{array}$ & $21 / 13$ & $\begin{array}{c}85 \\
137 / 139\end{array}$ & $\begin{array}{c}75 \\
138 / 138\end{array}$ & $\begin{array}{c}74 \\
137 / 138\end{array}$ & $\begin{array}{l}51-127 \\
134-143 /\end{array}$ & $\begin{array}{l}55-100 \\
134-143 /\end{array}$ & $\begin{array}{l}39-108 \\
125-147 /\end{array}$ \\
\hline $\begin{array}{l}\text { (21) ACTH response } \\
\text { (22) PBI ( } \mu \text { g./ } 100 \mathrm{ml} .) \\
\text { (23) Cholesterol (mg./100 }\end{array}$ & $\begin{array}{l}\ldots \\
0 \\
\text { ml.) }\end{array}$ & $\begin{array}{l}\ldots \\
\cdots\end{array}$ & $\begin{array}{c}19 / 17 \\
19 \\
13\end{array}$ & $\begin{array}{c}9 / 8 \\
9 \\
5\end{array}$ & $\begin{array}{l}25 / 23 \\
23 \\
20\end{array}$ & $\begin{array}{c}22 / 46 \\
5 \cdot 7 \\
200\end{array}$ & $\begin{array}{l}18 / 40 \\
5 \cdot 7 \\
163\end{array}$ & $\begin{array}{l}20 / 42 \\
5 \cdot 5 \\
207\end{array}$ & $\begin{array}{c}9-46 / 20-92 \\
2 \cdot 9-7 \cdot 4 \\
148-254\end{array}$ & $\begin{array}{c}6-29 / 11-73 \\
3 \cdot 5-7 \cdot 6 \\
108-200\end{array}$ & $\begin{array}{c}2-54 / 5-120 \\
3 \cdot 6-7 \cdot 9 \\
84-315\end{array}$ \\
\hline
\end{tabular}

poor response. The rate of growth in one was probably significantly increased by the hormone, but only to $3.8 \mathrm{~cm}$. in the first year, whereas a successful treatment produces a rate twice to three times this. The second had a similarly poor initial response and then developed antibodies. (Of all the other dwarfs in this section of the table one only, 3.14 , responded in this half-hearted way to $\mathrm{HGH}$; his bone age was $57 \%$ chronological age.) The fourth exception, 3.19, may conceivably be an undiagnosed case of gonadal dysgenesis with mosaicism, despite development of secondary sex characteristics and a normal XX/46 karyotype. On the other hand, of the 5 small normals with ratios below $65 \%$ on initial examination, 3 had ratios well above $65 \%$ on further examination a year or more later. Of the $9 \mathrm{LBW}$ dwarfs, 3 had bone age ratios of less than $65 \%$. Preliminary indications are that hyposomatotrophic dwarfs who respond to $\mathrm{HGH}$ usually have very retarded bone ages, with ratios below $65 \%$; LBW dwarfs mostly resemble normal small children in this characteristic.

Height SD score. In height SD score, as expected from our method of classification, the hyposomatotrophic dwarfs are much greater than the other two groups; their mean is $5 \cdot 2$ against the small normals mean of $2 \cdot 7$ and the LBW dwarf mean of 3.7. There is little overlap between small normals and hyposomatotrophic dwarfs; only 4 of the small normals had SD scores greater than 3.5 when first seen, and three of these a year or more later had changed to less than $3 \cdot 5$. On the other hand, 22 of the 25 hyposomatotrophic dwarfs had scores greater than $3 \cdot 5$, and on follow-up 2 of the 3 exceptions had changed to greater than $3 \cdot 5$. Thus, smallness to a degree that persistently gave an SD score greater than 3.5 caused us to place the child nearly always in the hyposomatotrophic dwarf category; conversely, children we ultimately felt were really small normals seldom had scores greater than 3.5. The LBW dwarfs overlapped both other categories; 4 out of 9 had scores below 3.5.

Skinfolds. All three groups contain both very thin and very fat members. But the hyposomatotrophic dwarfs are on average distinctly fatter than the small normals or LBW dwarfs. Whether this represents a physiological result of lack of growth hormone or only a brave attempt on the part of parents to increase calorie input to the maximum is not certain. The former seems more likely however, since two of us have found, in treating these cases with HGH, that children who respond well are fatter than those who respond badly, and that a good initial height response is usually accompanied by an initial fall of skinfolds (Tanner and Whitehouse, 1967).

Length of gestation and pregnancy conditions. There is little to distinguish the hyposomatotrophic dwarfs from the normals in length of gestation or the incidence of abnormal pregnancy: the LBWs, naturally, have more abnormal pregnancies. Three of the hyposomatotrophic dwarfs were adopted, which seems a high proportion.

Birthweight. Naturally the average birthweight of the LBW dwarfs is much below that of the others. It is interesting, however, that both the other categories have an average birthweight which is a little below the population mean. 
Parents' height. All three groups include some very small parents, but the LBW group does not include any very tall ones. Both mothers and fathers of this group tend to be small, especially the fathers.

Insulin sensitivity test. The means for the lowest blood sugar recorded in the test were $59 \mathrm{mg}$. for the small normals, $54 \mathrm{mg}$. for LBW dwarfs, and $45 \mathrm{mg}$. for hyposomatotrophic dwarfs. However, there was considerable overlap between the groups. By the criteria of sensitivity described in methods, taking the one-plus and two-plus cases together, no less than 12 of the small normals were sensitive compared with 9 insensitive; in LBWs 6 were sensitive and 2 insensitive; and in hyposomatotrophic dwarfs all except one were sensitive. Better differentiation might be obtained by looking at the two-plus sensitivity index. According to this, however, 8 normals and 3 LBWs were still sensitive, together with 15 out of 25 hyposomatotrophic dwarfs. Thus the degree of differentiation is no better. Why the small normals should appear sensitive to this test is not clear. Need to terminate the test because of hypoglycaemic symptoms is a better indication, for 10 out of 25 of the hyposomatotrophic dwarfs had to have their tests terminated, in contrast to two of the small normals and none of the LBW dwarfs. One of these normals was No. 1.19 , who at the time was $4 \cdot 3 \mathrm{SD}$ in height below the mean and had a bone age ratio of $69 \%$. But four years later, at age $17 \cdot 7$, he had reached the 8 th centile for height and undergone perfectly normal sex development without any treatment. The other child was also fairly obviously not a hyposomatotrophic dwarf.

Fasting blood sugar. The fasting blood sugars show the same thing as the insulin sensitivities; much overlap between the groups, but a lower average value for the hyposomatotrophic dwarfs.

Sodium. Accepting 134 or more $\mathrm{mEq} \mathrm{Na} / 1$. plasma as normal, marked abnormality was seen in 4 of the hyposomatotrophic dwarfs only, Nos. 3.6 and 3.25 having initial levels of 131, 3.14 130, and $3.4125 \mathrm{mEq} / \mathrm{l}$. Following ACTH, rises of 5, 12, 13, and $11 \mathrm{mEq} \mathrm{Na}$ were seen.

ACTH test. There is little difference between the groups with respect to either maximal or total response to ACTH. A below-normal maximal response was seen in 5 of $9 \mathrm{LBW}$ dwarfs, 11 of 18 small normals, and 15 of 25 hyposomatotrophic dwarfs. The total response was below normal in
5 of 9 LBW dwarfs, 7 of 16 small normals, and 10 of 23 hyposomatotrophic dwarfs.

In 7 of the dwarfs and 1 of the normals the test was repeated one to four years later. In the small normal, No. 1.10, the initial maximal 24-hour excretion was $16 \mathrm{mg}$; 2 years later it was $12 \mathrm{mg}$. (He had HGH for 1 year before the second test, with no response.) Of the dwarfs, No. 3.1, at age $2 \cdot 9$, excreted $19 \mathrm{mg}$., and after 3 years on $\mathrm{HGH}$ with a good response, excreted $20 \mathrm{mg}$. No. 3.2 excreted only $3 \mathrm{mg}$. at age $2 \cdot 2$ but $17 \mathrm{mg}$. at age $2 \cdot 9$, having had HGH with good response between these two dates. No. 3.12 excreted $15 \mathrm{mg}$. at age $5 \cdot 0$, and $22 \mathrm{mg}$. at age $7 \cdot 3$ after $\mathrm{HGH}$, with good response; but at age $8 \cdot 8$, still following continuous $\mathrm{HGH}$ with good response, the excretion dropped to $6 \mathrm{mg}$. No. 3.18 had values of 26,21 , and 38 at ages $11 \cdot 1$, $12 \cdot 5$, and $15 \cdot 8$. No. 3.17 had values of 19 and 15 at age $10 \cdot 3$ and $13 \cdot 8$. No. 3.14 excreted 36 and 15 at ages $8 \cdot 1$ and $11 \cdot 9$, having had a poor response to $\mathrm{HGH}$ in the interim. Thus some children stay fairly constant in response and others seem to change; but the relation of this to diagnosis or treatment is by no means clear.

Thyroid function. Estimations of PBI were all within normal limits apart from a low value in No. 1.10, who, however, had a normal 132 I uptake, and No. 3.22. No. 3.3 was already on thyroxine as a deficiency had been demonstrated previously elsewhere.

Cholesterol. The upper limit of normal for cholesterol is ill defined, but usually accepted as $220 \mathrm{mg} . / 100 \mathrm{ml}$. Four of the small normals exceeded this value, none of the LBW dwarfs, and 9 of 18 hyposomatotrophic dwarfs. In only one patient, No. 3.12, did the value exceed $300 \mathrm{mg}$.

Other biochemical investigations. Estimations of blood urea and plasma calcium were normal except that in No. 3.3 the blood urea was raised to $60 \mathrm{mg} . / 100 \mathrm{ml}$. and in No. 3.17 the calcium was only $8.0 \mathrm{mg}$. $/ 100 \mathrm{ml}$. (lower normal $=8 \cdot 5$ ).

\section{Discussion}

The division of these small children into small normals, some with a delay of growth, and hyposomatotrophic dwarfs, who, we think, are unable to secrete or to utilize growth hormone, has been made on clinical and auxological grounds. We have followed most of the children for several years, and their course of growth has influenced us greatly in assigning children to one or the other group. We have also assumed that a very short child who 
responds well to $\mathrm{HGH}$ is probably lacking in that substance.

Thus when we find that hyposomatotrophic dwarfs, according to our classification, are best defined by their height SD score being above 3.5 and their bone age being less than $65 \%$ of their chronological age, we are involved in a circular argument. But the biochemical findings are not subject to this, since our classification is entirely independent of them. Disappointingly, we find that the insulin sensitivity test, at least as we perform it, has only a screening-out value. If the insulin sensitivity is normal, then it is very unlikely that the child is a hyposomatotrophic dwarf, according to our criteria. The converse does not hold; too many normal small children are sensitive for us to be able to conclude anything from a positive test.

The ACTH response is of little help in differential diagnosis. This may be partly because some or most of these children lack only growth hormone and not ACTH, and partly because, again, a good proportion of small normals fail to respond to ACTH in the way that larger children do.

There seems to be little relation between insulin sensitivity and ACTH response. Amongst the small normals there are 5 children who are sensitive and non-responding; 6 who are sensitive but respond to ACTH; 5 who are insensitive and non-responding; and 3 who are insensitive and respond normally. Amongst the dwarfs 9 are sensitive and respond normally to ACTH, and 14 are sensitive and fail to respond normally. The one insulin insensitive child (No. 3.20) also responds normally, and might not be a true hyposomatotrophic dwarf; but on clinical and growth progress grounds we cannot with honesty classify her as anything else.

Our findings in respect of bone age and height agree well with those of Prader, Illig, Széky, and Wagner (1964), Trygstad (1965), and Wright, Brasel, Aceto, Finkelstein, Kenny, Spaulding, and Blizzard (1965). Wright and his colleagues found that the water load test of adrenal function gave sometimes normal and sometimes abnormal values in cases similar to our hyposomatotrophic dwarfs, just as our ACTH test did. The metyrapone test also gave some normal and some abnormal responses in Wright's cases, as it did in Trygstad's pituitary dwarfs; though it was never abnormal in his cases of 'constitutional growth retardation'.

Trygstad reported that his insulin-glucose tolerance test distinguished pituitary dwarfs, confirmed by response to growth hormone, from children with constitutional retardation very efficiently indeed, with only one out of 25 wrongly classified. This, the subcutaneous insulin test in our hands fails to do, though whether because of the nature of the test or of our material we cannot at present say. Prader et al. use an intravenous insulin test and 'attach much importance' to it, but have not, to our knowledge, reported results in small normals. It will be recalled that our test does give positive results in very nearly all our abnormals, so the problem is not one of lack of sensitivity of the test, but of the large number of false positives.

Growth hormone assays have been made on some of our patients and are in progress on others. We hope they will throw further light on a still confused situation, but we doubt that they will supply more than a partial answer. At present the best simple guide to the diagnosis of the growth hormonelacking child seems to be the growth curve of height, which is much depressed from soon after birth, combined with a very delayed bone age in the absence of hypothyroidism.

\section{Summary}

Fifty-five children suffering from short stature but without known metabolic, chromosomal, or gross nervous system defects have been classified as small normal children (21), low birthweight dwarfs (9), and hyposomatotrophic dwarfs (25). The classification was made by reference to clinical criteria, growth progress over several years, and, in some cases, a positive response to human growth hormone administration. On these criteria, small normals and hyposomatotrophic (or presumed growth hormone-lacking) dwarfs can best be diagnosed at initial interview by (a) a height which is 3.5 standard deviations or more below the mean for the child's chronological age, combined with (b) a bone age on the Tanner-Whitehouse standards which is $65 \%$ or less of the chronological age.

A subcutaneous insulin sensitivity test, if normal, tends to rule out the diagnosis of hyposomatotrophic dwarfism, but if positive is not very significant, in that a considerable number of small normal children appear to be sensitive. The response to ACTH is without value for distinguishing the two categories.

We wish to thank our colleagues in The Hospital for Sick Children for allowing us to study their patients, Dr. R. W. H. Edwards for supervising the estimation of ACTH response, Professor P. Polani and Dr. J. L. Hamerton for doing the karyotype investigations, Dr. D. R. C. Willcox of Bethlem Royal Hospital for estimating the PBIs, and Dr. M. Barratt for help with the investigations.

We are indebted to the Joint Research Board of The Hospital for Sick Children and the Institute of Child Health for financial support, and one of us (J.M.T.) wishes to acknowledge gratefully grants from the Nuffield Foundation and the Medical Research Council which have each supported portions of this work. 
REFERENCES

Black, J. (1961). Low birth weight dwarfism. Arch. Dis. Childh., 36, 633.

Clayton, B. E., Edwards, R. W. H., and Renwick, A. G. C. (1963). Adrenal function in children. ibid., 38, 49.

Daniel, W. A. (1941). A study of insulin tolerance and glucose tolerance tests on normal infants. F. Pediat., 19, 789.

Grossmann, A., and Grossman, G. F. (1955). Protein-bound iodine by alkaline incineration and a method for producing a stable cerate colour. F. clin. Endocr., 15, 354

Mason, S., and Tanner, J. M. (1967). Human growth hormone in the treatment of dwarfism. In Recent Advances in Endocrinology, ed. H. Gardiner Hill. Churchill, London.

Prader, A., Illig, R., Széky, J., and Wagner, H. (1964). The effect of human growth hormone in hypopituitary dwarfism. Arch. Dis. Childh., 39, 535.

Tanner, J. M. (1958). The evaluation of physical growth and development. In Modern Trends in Paediatrics (second series), ed. A. Holzel and J. P. M. Tizard, p. 325. Butterworth, London.

, and Whitehouse, R. H. (1962). Standards for subcutaneous fat in British children. Percentiles for thickness of skinfolds over triceps and below scapula. Brit. med. F., 1, 446.

- and - (1967). The effect of human growth hormone on subcutaneous fat thickness in hyposomatotrophic and parahypopituitary dwarfs. F. Endocr. In the press.

-, - and Healy, M. J. R. (1962). Standards for Skeletal Maturity Based on a Study of 3000 British Children. II. The scoring system for all 28 bones of the hand and wrist. International Children's Centre, Paris.

- - and Takaishi, M. (1966). Standards from birth to maturity for height, weight, height velocity and weight velocity: British children, 1965. Arch. Dis. Childh., 41, 454 and 613.

Trygstad, O. (1965). The insulin-glucose tolerance test in pituitary growth retardation. ibid., 40, 508 .

Warkany, J., Monroe, B. B., and Sutherland, B. S. (1961). Intrauterine growth retardation. Amer. F. Dis. Child., 102, 249.

Wilkinson, R. H. (1960). Chemical Micro-Methods in Clinical Medicine. Charles C. Thomas, Springfield, Illinois.

Wright, J. C., Brasel, J. A., Aceto, T., Finkelstein, J. W., Kenny, F. M., Spaulding, J. S., and Blizzard, R. M. (1965). Studies with human growth hormone (HGH). An attempt to correlate metabolic response during short-term administration with linear growth during prolonged therapy. Amer. F. Med., 38, 499. 